\title{
Sustainable development of the Baikal natural territory
}

\author{
Sergey Kirillov*, Natalia Sedova, and Mikhail Slipenchuk \\ Lomonosov Moscow State University, Department of Environmental Management, 119991 Moscow, \\ Russia
}

\begin{abstract}
The Sustainable Development Goals (SDGs) are increasingly being integrated into the policies of modern states, and the Russian Federation is no exception. The World Natural Heritage site Lake Baikal is of special attention to the world community. The study is based on the need to achieve 17 SDGs both in the Russian Federation and in the Baikal region. For the Baikal natural territory, priority areas were identified for achieving sustainable development goals in the economic, environmental and social spheres. Then the analysis of the current situation in areas that need to be improved to achieve sustainable development was made. The most difficult moment in the implementation of sustainable development goals on Lake Baikal is to achieve a balance between socio-economic development and the goals of protecting the Baikal ecosystem.
\end{abstract}

\section{Introduction}

The Sustainable Development Goals (SDGs) are increasingly being integrated into the policies of modern states, and the Russian Federation is no exception. This is expressed both in the inclusion of individual goals and objectives of sustainable development, as well as individual indicators reflecting the degree of their achievement, in the country's strategic and program documents, and in the formation of a full-fledged system of statistical accounting of SDG indicators.

The national project "Ecology" is aimed at ensuring the environmental safety of Russia, which includes the federal projects "Clean Water", "Rehabilitation of the Volga", "Preservation of Lake Baikal", "Preservation of unique water bodies", "Preservation of forests", "Preservation of biological diversity" and "Development of Ecological Tourism.

Studies of the ecological and economic development of the Baikal natural territory are of interest to many Russian and foreign scientists. The main areas of study are in the sphere of sustainable development [1-3], green economy [4-5], tourism development [6-11], the use of the recreational potential [12-13], conservation and use of aquatic [14-15] and forest resources [16], human impact on ecosystems [17]. It is especially worth emphasizing the study of economic activity based on the specialization of the region [18] for energy development [19], construction [20], organic agriculture [21]. Scientists note the need to

\footnotetext{
*Corresponding author: eco-msu@mail.ru
} 
apply a systematic approach [22], strategy development [23] and development programs [24] followed by the assessment of the results [25].

\section{Research methodology}

The study is based on the need to achieve 17 SDGs both in the Russian Federation and in the Baikal region. For the Baikal natural territory, priority areas were identified for achieving sustainable development goals in the economic, environmental and social spheres. Then the analysis of the current situation in areas that need to be improved to achieve sustainable development was made.

The applied SWOT analysis makes it possible to highlight the strengths and weaknesses of the development of the Baikal natural territory, taking into account external opportunities and threats for it. On the basis of the SWOT analysis, the strategy and programs of sustainable development can be selected in the future, followed by the assessment of the final results.

A great contribution to the study of the Baikal region to ensure sustainable development was made by the Department of Environmental Management of the Geographical Faculty of Moscow State University. The staff of the department carried out comprehensive studies in the Baikal region for the period from 2013 to 2019. Initially, the collection of data on existing natural resources was carried out, the landscape structure of the territory was studied and corresponding maps were compiled. At the second stage, the social and economic conditions of environmental management were analyzed, information about the natural and cultural heritage was collected. At the third stage, the features of the impact of various types of nature management on the state of the environment were studied. At the final stage, ecological and economic assessments of ecosystem services were carried out on model territories, including taking into account environmental problems for the Baikal region.

\section{Research results}

Russia's special responsibility to the world community is to fulfill the task of preserving the World Natural Heritage site - Lake Baikal, which is the largest in Asia and the deepest in the world. Baikal's area is about 32 thousand square $\mathrm{km}$. According to the Federal Service for Hydrometeorology and Environmental Monitoring, for Lake Baikal, whose water reserves are very large and incomparable with their annual changes, the volume is considered unchanged from year to year $-23,000$ cubic $\mathrm{km} /$ year. The Baikal basin is one of the most significant centers of speciation: more than 2500 species and subspecies of animals live here, among them endemics make up more than $60 \%$. The unique ecosystem of the lake ensures the constant production of clean fresh water. The natural landscapes of the lake coast are rich in thermal and mineral springs, have a special humanitarian, aesthetic and recreational value. The main tasks are to preserve the integrity of the unique landscapes of the Baikal coast, landscape and biological diversity, and the purity of the lake waters. The inclusion of Baikal and adjacent territories into the boundaries of federal protected areas has significantly increased their legal protection, contributes to a more efficient organization of scientific and environmental activities and the sustainable development of various forms of educational tourism. Also, the Baikal natural territory has a special status, fixed at the international level, in connection with the inclusion of Lake Baikal in the list of the World Natural Heritage sites.

Assessing the current state and progress in achieving the Sustainable Development Goals, the following successes and challenges can be identified (Table 1). The main successes were achieved within the framework of the federal project "Preservation of Lake Baikal", which is being implemented from January 1, 2019 to December 31, 2024. 
Table 1. Priority directions for achieving sustainable development goals for the Baikal natural territory.

\begin{tabular}{|c|c|c|c|c|}
\hline No & Sustainable development goals & Economic & Environmental & Social \\
\hline 1 & End poverty in all its forms everywhere & & & $*$ \\
\hline 2 & $\begin{array}{l}\text { End hunger, achieve food security and } \\
\text { improved nutrition and promote sustainable } \\
\text { agriculture }\end{array}$ & * & * & * \\
\hline 3 & $\begin{array}{l}\text { Ensure healthy lives and promote well-being } \\
\text { for all at all ages }\end{array}$ & * & * & * \\
\hline 4 & $\begin{array}{c}\text { Ensure inclusive and equitable quality } \\
\text { education and promote lifelong learning } \\
\text { opportunities for all }\end{array}$ & * & & * \\
\hline 5 & $\begin{array}{c}\text { Achieve gender equality and empower all } \\
\text { women and girls }\end{array}$ & & & * \\
\hline 6 & $\begin{array}{c}\text { Ensure availability and sustainable } \\
\text { management of water and sanitation for all }\end{array}$ & $* *$ & $* *$ & * \\
\hline 7 & $\begin{array}{l}\text { Ensure access to affordable, reliable, } \\
\text { sustainable and modern energy for all }\end{array}$ & $*$ & & $*$ \\
\hline 8 & $\begin{array}{l}\text { Promote sustained, inclusive and sustainable } \\
\text { economic growth, full and productive } \\
\text { employment and decent work for all }\end{array}$ & ** & & ** \\
\hline 9 & $\begin{array}{l}\text { Build resilient infrastructure, promote } \\
\text { inclusive and sustainable industrialization and } \\
\text { foster innovation }\end{array}$ & ** & * & \\
\hline 10 & $\begin{array}{c}\text { Reduce inequality within and among } \\
\text { countries }\end{array}$ & & & ** \\
\hline 11 & $\begin{array}{l}\text { Make cities and human settlements inclusive, } \\
\text { safe, resilient and sustainable }\end{array}$ & * & * & * \\
\hline 12 & $\begin{array}{l}\text { Ensure sustainable consumption and } \\
\text { production patterns }\end{array}$ & ** & ** & $* *$ \\
\hline 13 & $\begin{array}{l}\text { Take urgent action to combat climate change } \\
\text { and its impacts }\end{array}$ & ** & ** & * \\
\hline 14 & $\begin{array}{l}\text { Conserve and sustainably use the oceans, seas } \\
\text { and marine resources for sustainable } \\
\text { development }\end{array}$ & & & \\
\hline 15 & $\begin{array}{l}\text { Protect, restore and promote sustainable use } \\
\text { of terrestrial ecosystems, sustainably manage } \\
\text { forests, combat desertification, and halt and } \\
\text { reverse land degradation and halt biodiversity } \\
\text { loss }\end{array}$ & $*$ & $* *$ & $*$ \\
\hline 16 & $\begin{array}{l}\text { Promote peaceful and inclusive societies for } \\
\text { sustainable development, provide access to } \\
\text { justice for all and build effective, accountable } \\
\text { and inclusive institutions at all levels }\end{array}$ & & & * \\
\hline 17 & $\begin{array}{l}\text { Strengthen the means of implementation and } \\
\text { revitalize the Global Partnership for } \\
\text { Sustainable Development }\end{array}$ & $*$ & $*$ & $*$ \\
\hline
\end{tabular}

The goal of the project is the ecological improvement of Baikal by reducing the volume of polluted waste water discharges into the lake and other water bodies of the Baikal natural territory, as well as reducing the total area of territories exposed to high and extremely high pollution and affecting Lake Baikal. The federal project includes a set of measures to reduce the total area of territories exposed to high and extremely high pollution and affecting Lake Baikal; on the modernization and construction of treatment facilities necessary for the 
purification of polluted wastewater entering the lake and other water bodies of the Baikal natural territory; for the construction of engineering protection structures; for the preservation and reproduction of the unique aquatic biological resources of Lake Baikal.

In 2013, the Baikal Pulp and Paper Mill (BPPM), which had a negative impact on the Baikal ecosystem, ceased operations. The need to eliminate environmental damage from the BPPM activity arose almost simultaneously with its launch. Later, the construction of the plant on the shore of the lake was recognized as a strategic mistake. According to official data, over half a century of its work, more than 6.2 million cubic meters of hazard class 4 waste have accumulated and are stored in 14 sludge collectors: sludge-lignin, ash, bark, industrial, household waste, alkali-containing liquid. The authorities of the Irkutsk region were faced with the urgent need to eliminate waste accumulated as a result of the BPPM activity. The first phase of liquidation was announced at the beginning of 2017, then the deadlines were shifted to the end of the year, then to 2018.

In 2019, another attempt was made to reclaim it within the framework of the national project "Ecology", but this turned out to be technologically difficult and expensive. The difficulty lies in the fact that waste is stored in so-called storage cards, which can overflow, and then liquid masses from the upper (seventh) card will flow into the (sixth) one below it, from it - further, and so on to the lower card, so that then pour into Baikal like a poisonous stream. In the case of a mudflow descending onto storage cards a catastrophic scenario can develop.

Social status in the Baikal natural territory differs by regions (Table 2).

Table 2. Social status of the population within the Baikal natural territory in the constituent entities of the Russian Federation (2017).

\begin{tabular}{|c|c|c|c|}
\hline Indicators & $\begin{array}{c}\text { The Republic of } \\
\text { Buryatia }\end{array}$ & $\begin{array}{c}\text { Irkutsk } \\
\text { region }\end{array}$ & $\begin{array}{c}\text { Zabaykalsky } \\
\text { Krai }\end{array}$ \\
\hline Population (thousand people) & 961 & 1358 & 163 \\
\hline Share of the total population (\%) & 97.6 & 56.5 & 15.2 \\
\hline Share of urban population (\%) & $59.4^{* *}$ & 85.7 & 38.4 \\
\hline $\begin{array}{c}\text { Fertility rate (persons per 1000 } \\
\text { inhabitants) }\end{array}$ & $16.3^{*}$ & 13.8 & 13 \\
\hline $\begin{array}{c}\text { Mortality rate (people per 1000 } \\
\text { inhabitants) }\end{array}$ & $11.4^{* *}$ & 12 & 13.6 \\
\hline Unemployed (thousand people) & $42.4^{* * *}$ & $110.4^{* * *}$ & $57.3^{* * *}$ \\
\hline $\begin{array}{c}\text { Average monthly salary (thousand } \\
\text { rubles) }\end{array}$ & $32.2^{* * *}$ & $38.1^{* * *}$ & 30.8 \\
\hline Poverty rate (\% of population) & $18.5^{* * *}$ & $20^{* * *}$ & $21.4^{* * *}$ \\
\hline $\begin{array}{c}\text { The number of crimes per 100,000 } \\
\text { population }\end{array}$ & $2399^{* * *}$ & $1905^{* * *}$ & 2738 \\
\hline $\begin{array}{c}\text { Patients with tuberculosis registered in } \\
\text { the dispensary per 100,000 population }\end{array}$ & $203^{* *}$ & $233^{* * *}$ & $128^{* * *}$ \\
\hline
\end{tabular}

$$
*-2016, * *-2015, * * * \text { - all over the Subject. }
$$

Invasive (alien) species are now recognized as one of the greatest threats to global biodiversity. The problem of invasive species in the Russian Federation poses the greatest threat to the biodiversity of regions characterized by the presence of endemics, relict forms and endangered species, which largely include the flora and fauna of Lake Baikal. The national project "Ecology" provides for the formation of the regulatory framework for the conservation and reintroduction of rare and endangered wildlife objects, including the approval of the List of rare and endangered wildlife objects, the development and approval of the conservation strategy and programs for restoration and reintroduction for priority species. 
Spirogyra is especially dangerous for Baikal endemics. It destroys endemic Baikal sponges, thanks to which the water in the lake remains crystal clear. It also occupies the spawning grounds of the yellowfly goby, which feeds on the Baikal omul. In some areas, the shores of Lake Baikal are covered with a thick layer of rotted Spirogyra. This significantly affects the quality of water - it becomes unsuitable for human and animal consumption. It takes a lot of effort to remove algae from the beach. You have to dig almost 30 centimeters deep. Fishing also becomes nearly impossible. Thick ooze fills boats and nets. Nowadays scientists from the Limnological Institute of the Siberian Branch of the Russian Academy of Sciences are actively studying the Baikal spirogyra. In the fall of 2020, 32 regions were examined and 270 samples were taken in the depth range from the water's edge to 6-7 m, as a result of which data on the mass development of Spirogyra and other algae alien to Baikal were obtained. So far, researchers have not come to the consensus on whether Spirogyra poses a real threat to the lake or whether the listed consequences are the result of a combination of many factors. But already now, the adverse consequences of the spread of algae are obvious, and the problem has already gone very far.

At present, in the Baikal region, one of the key problems in the sphere of protection of land animal world is also poaching and the associated turnover of products from illegal hunting. In Russia, there are strict sanctions for illegal production, maintenance, acquisition, storage, transportation, shipment and sale of especially valuable species of wild animals listed in the Red Book of Russia and (or) protected by international treaties. Poaching here is mainly focused on catching seals and omul during the spawning period. As a result, the population is declining. And the reason lies not only in the capture, but in the stress of the remaining fish, which should be at rest during spawning. According to the statistics, the catch by a poacher during the spawning period of one fish leads to a shortage of 4-10 individuals in the next year.

In the sphere of forest conservation, the policy is being pursued to improve forest management, including optimization of the state forest management service, and streamlining of forest relations. An important role in the preservation of forest resources is played by timber industry enterprises, introducing models of responsible forest management into their activities. In matters of forest management, the main problems for the Baikal region are: destruction and damage of forests as a result of forest fires, forest diseases, illegal logging of forest plantations and illegal trade in timber, insufficient quality and rates of reforestation and afforestation. The first threat to the forests of Lake Baikal is logging. There is a confrontation with the commercial structures of Buryatia, which, even in specially protected natural areas, in particular in the Baikal reserve, cut down forests under various pretexts. Almost all timber goes to China. Forest fires have also become a real disaster. According to Greenpeace Russia estimates, in 2015 alone, around Lake Baikal in the Irkutsk region and Buryatia, from 1.2 million to 1.5 million hectares of forests were damaged by fire.

Thus, in the Severobaikalsk region of the Republic of Buryatia, within the framework of the substantiation of the creation of the territory of traditional nature management (TTP) of the Evenks, the natural resource potential of traditional nature management was identified. The ecological services of geosystems were determined and their ecological and economic assessment was carried out. As a result the map of the unit cost of environmental services of natural territorial complexes was made up. The information collected made it possible to make an approximate assessment of such direct ecosystem services as hunting, fishing, reindeer husbandry, harvesting of wild plants, and the recreational value, which amounted to about $\$ 126$ thousand per year.

The development of tourist and recreational clusters on the territory of the Baikal region was also studied using the example of the general economic zone of the tourist and recreational type "Baikal Harbor". The "Baikal Harbour" was created in the Pribaikalsky District of the Republic of Buryatia on the eastern coast of Baikal Lake. We have analyzed 
current environmental and economic situation on its territory. It has a variety of resources and attractive features which can be used for territory development as a part of this zone. Also it is important for the economy of the Republic of Buryatia to encourage the growth of the "Baikal Harbour". The SWOT-analysis revealed the positive and negative factors of territory development (Figure 1).

\section{Helpful}

to achieving the objective

\section{Harmful}

to achieving the objective

\begin{tabular}{|c|c|c|}
\hline 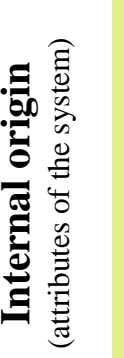 & 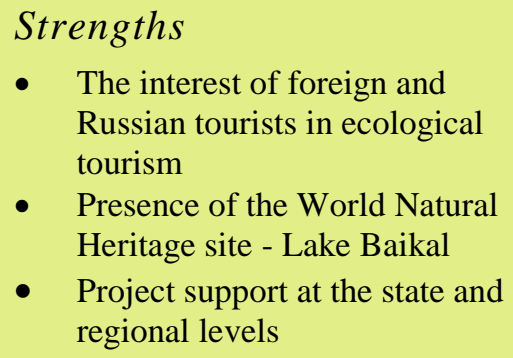 & $\begin{array}{l}\text { Weaknesses } \\
\text { - Lack of awareness of the } \\
\text { project and location } \\
\text { - Insufficient number of } \\
\text { investments } \\
\text { - High cost of air and railway } \\
\text { tickets }\end{array}$ \\
\hline 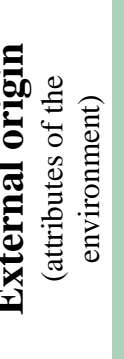 & $\begin{array}{l}\text { Opportunities } \\
\text { - Year-round tourist reception } \\
\text { - The possibility of temporary } \\
\text { accommodation (camping) in } \\
\text { high season (July-August) } \\
\text { - Offering a variety of } \\
\text { accommodation on cost } \\
\text { categories }\end{array}$ & $\begin{array}{l}\text { Threats } \\
\text { - Insufficient number of tourists } \\
\text { - Inadequate infrastructure and } \\
\text { the high cost } \\
\text { - High anthropogenic load on } \\
\text { the territory }\end{array}$ \\
\hline
\end{tabular}

Fig. 1. SWOT-analysis of tourism development in the Baikal region

According to our research the appearance of such zones in the Baikal region will lay the ground for changing the area from the depressed into the prosperous one. Moreover, the creation of such clusters promotes effective interaction between government agencies, scientific and public organizations, as well as business companies and non-governmental organizations, which have recently become a serious agent for environmental conservation.

\section{The discussion of the results}

A new decision was made to connect the Rosatom State Nuclear Energy Corporation to the waste reclamation of the Baikal Pulp and Paper Mill. More precisely, the Federal State Unitary Enterprise "Federal Environmental Operator" (FEO), which is entrusted with the mission of reclamation of objects of accumulated environmental damage to the environment within the framework of the federal project "Clean Country". The Rosatom intends to dehydrate lignin on the storage cards and make a technical soil from it (adding sorbents, ash residues). "The proposed reclamation scheme will resemble a carousel with the extraction of lignin from some storage cards, mixing it with ash and slag from others to obtain techno-soil, and then placing the resulting composition in the vacated cards. However, they will be filled only partially, relatively speaking, by half. To the top, they will be covered with harmless soil obtained by fermentation of industrial soil. It is proposed to plant green spaces on the soil," the Bellona Environmental Legal Center described the process. 
According to Andrey Lebedev, director of the implementation of state and industry programs in the field of ecology of the Rosatom, all this is still only preliminary technological approaches. Now the FEO is conducting engineering surveys, which are almost completed all technological solutions must be tested empirically and confirmed by an examination. Thus, the issue, on which at the sessions of the World Heritage Commission Russia constantly received comments from the UN experts about the non-opposition of the authorities to the ever-increasing risks of environmental problems that threaten the unique reservoir, has not been resolved.

In terms of preserving the aquatic ecosystems of Lake Baikal, measures are being taken to clean up water areas, as well as to restore and preserve aquatic biological resources. In addition, within the framework of the federal project "Preservation of unique water bodies" of the national project "Ecology", all-Russian actions for cleaning up reservoirs and their shores "Water of Russia" were organized. Since 2020, Lake Baikal has one of the most stringent requirements for the purity of wastewater in the world. In accordance with the new requirements for wastewater in Baikal, quantitative indicators of the permissible concentration of harmful substances in wastewater discharged within the central and buffer ecological zones of the Baikal natural territory are determined. This will make it possible to design and build treatment facilities near Lake Baikal using modern technologies. However, in the central ecological zone of the Baikal natural territory, only 12 treatment facilities operate, and during their operation numerous violations of laws and sanitary standards are allowed. There are not enough treatment facilities, and new ones are not being built, although they are provided for by the federal target program and the federal project "Preservation of Lake Baikal" of the national project "Ecology". Also, the issue of a sharp decrease in the discharge of polluted waters into Baikal during the operation of ships has not been resolved and the negative anthropogenic impact on the coastal zone of Lake Baikal is increasing due to the spontaneous development of tourism.

\section{Conclusion}

The most difficult moment in the implementation of sustainable development goals on Lake Baikal is to achieve a balance between socio-economic development and the goals of protecting the Baikal ecosystem. Projects carried out in the Baikal natural territory must necessarily undergo a state ecological expertise, while all types of economic activities that have a negative impact on Lake Baikal are prohibited or restricted.

According to the co-chairman of the All-Russian public organization "Social and Environmental Union" Sergei Shapkhaev (a well-known scientist and ecologist), all the existing problems of Lake Baikal, which today need to be solved, lie mainly in the field of management and scientific developments. He was confident that environmental monitoring, strategic planning of water resources management and compliance with international standards would help preserve the unique lake. On the global scale, the solution to the problems of the unique lake, which the expert proposes, seems both obvious, and at the same time almost unrealizable: just when using the resources of the Baikal natural territory, the preservation of the Baikal ecosystem should always remain a priority.

The recent policy in the field of environmental protection in Russia is aimed at the development of rational use of natural resources and the preservation of terrestrial ecosystems. In general, the extensive and comprehensive legislative framework formed in Russia in the field of nature management and environmental protection is evolving towards the development of environmental principles and increasing environmental responsibility, detailing and deepening state regulation of the rational use and protection of natural resources, improving the distribution of powers between levels of government (federal, regional) and local self-government, improving control and oversight activities, developing 
institutions of public control and enhancing the role and participation of civil society in ensuring the constitutional rights of citizens to a healthy environment. It is very important to ensure the participation of a wide range of stakeholders and thus develop the interest of the authorities, the scientific community, business, to participate in the implementation of the SDGs at the national level.

This research was performed according to the Development program of the Interdisciplinary Scientific and Educational School of Lomonosov Moscow State University «Future Planet and Global Environmental Change» and within the framework of the state assignment "Sustainable development of territorial nature management systems" (project No. 121051100162-6).

\section{References}

1. T. Garmaeva, Lakes \& Reservoirs: Research \& Management, 6(3), 253(2001)

2. S. Kirillov, M. Slipenchuk, T. Zengina, International Journal of Innovation and Sustainable Development, 10(1), 57 (2016)

3. V. Mantatov, L. Mantatova, Leadership for the Future Sustainable Development of Business and Education (Springer, Cham, 2018)

4. A. Bilgaev, S. Dong, F. Li, H. Cheng, E. Sadykova, A. Mikheeva, Sustainability, 12(9), 3767 (2020)

5. A. Bilgaev, S. Dong, F. Li, H. Cheng, A. Tulohonov, E. Sadykova, A. Mikheeva, Sustainability, 13(1), 157 (2021)

6. V.P. Chizhova, M.V. Slipenchuk, S.N. Kirillov, World applied sciences journal, 30(30), 101-103 (2014)

7. D.V. Dayneko, V.V. Dayneko, IOP Conference Series: Earth and Environmental Science, 190(1) (2018)

8. A.N. Dunets, V.N. Ivanova, A.L. Poltarykhin, Entrepreneurship and Sustainability Issues, 6(4), 2207 (2019)

9. S. Kirillov, N. Sedova, M. Slipenchuk, E. Vorobyevskaya, European Journal of Sustainable Development, 9(3), 179-179 (2020)

10. M.V. Kuklina, A.I. Trufanov, N.E. Krasnoshtanova, M.V. Makarov, E. Altangerel, IOP Conference Series: Earth and Environmental Science, 751(1), 012012 (2021)

11. S.M. Nikonorov, S.V. Solovieva, I.Yu Khovavko, E3S Web of Conferences, 208 (2020)

12. Zh.V. Atutova, D.V. Kobylkin, M. Zhao, IOP Conference Series: Earth and Environmental Science, 629(1) (2021)

13. O.V. Evstrop'eva, Geography and natural resources, 34(1), 61(2013)

14. T. Bardakhanova, Journal of Geoscience and Environment Protection, 3(6), 39 (2015)

15. Y. Hosaka, C. Saraswat, A.T. Moe, P. Kumar, A.L. Ramanathan, Journal of Climate Change, 2(1), 61 (2016)

16. I.V. Bychkov, G.M. Ruzhnikov, R.K. Fedorov, A.K. Popova, Journal of Physics: Conference Series, 1864(1), 012111 (2021)

17. K.P. Brown, A. Gerber, D. Bedulina, M.A. Timofeyev, Wiley Interdisciplinary Reviews: Water e1528 (2021)

18. N.A. Ippolitova, N.V. Rogovskaya, IOP Conference Series: Earth and Environmental Science, 629(1), 012065 (2021)

19. S.Y. Muzychuk, R.I. Muzychuk, IOP Conference Series: Earth and Environmental Science, 272(3) (2019) 
20. I. Karnaukh, A. Mikheeva, S. Ayusheeva, T. Bardakhanova, MATEC Web of Conferences, 193, 05019 (2018)

21. O.A. Altaeva, E.G. Imeskenova, O.M. Chibikova, IOP Conference Series: Earth and Environmental Science, 395(1) (2019)

22. A.K. Tulokhonov, Geography and Natural Resources, 30(3), 224 (2009)

23. K. Gunzenova, European Journal of Sustainable Development, 9(2), 183 (2020)

24. A.K. Tulokhonov, Sustainable Development of the Lake Baikal Region (Springer, Berlin, Heidelberg, 2000)

25. S. Kirillov, M. Slipenchuk, E. Vorobyevskaya, IV International Scientific and Practical Conference Anthropogenic Transformation of Geospace: Nature, Economy, Society (ATG 2019) (Atlantis Press, 2020) 